\section{Production System and Cultivar Effects on the Development of Skin Separation or "Silvering" in Bell Pepper Fruit}

\author{
Christian A. Wyenandt ${ }^{1,5,10}$, Wesley L. Kline ${ }^{2,6}$, \\ Daniel L. Ward ${ }^{3,7,8}$, and Nancy L. Brill ${ }^{4,9}$
}

AdDitional INDEX wORDs. Capsicum annumm, phytophthora crown rot, Phytophthora capsici

SuMMARY. From 2006 to 2008 , four different production systems and five bell pepper cultivars (Capsicum annuum) with either no resistance (Alliance and Camelot), tolerance (Revolution), or resistance (Paladin and Aristotle) to the crown rot phase of phytophthora blight (Phytophthora capsici) were evaluated for the development of skin separation or "silvering" in fruit at a research facility and four commercial vegetable farms in southern New Jersey. Cultivar, production system, and year, each had a significant effect on the total percentage of fruit with skin separation and marketable yield. The percentage of bell pepper fruit with skin separation was higher in both phytophthora-resistant cultivars compared with the phytophthora-susceptible cultivars across all four production systems. Marketable yield was highest when bell peppers were grown in double rows on raised beds with black plastic mulch and drip irrigation compared with bell peppers grown on single rows on raised beds with black plastic mulch and drip irrigation and bell peppers grown on single rows on raised, bare ground beds with buried drip irrigation. Marketable yields were lowest when bell peppers were grown in single rows on high, ridged beds with overhead irrigation. Results of this study suggest that the development of skin separation or "silvering" in fruit is more closely associated with genotype than type of production system.

$\mathrm{E}$ ach year, over 3000 acres of bell and nonbell peppers are grown in New Jersey for fresh market and processing [U.S. Department of Agriculture (USDA), 2012]. New Jersey bell pepper production represents about $5.5 \%$ of the total U.S. production acreage and has an estimated value of over $\$ 12$ million (USDA, 2012). Phytophthora capsici,

${ }^{1}$ Department of Plant Biology, Rutgers University, Rutgers Agricultural Research and Extension Center, Bridgeton, NJ 08302

${ }^{2}$ Department of Agricultural and Resource Management Agents, Rutgers Cooperative Extension, 291 Morton Avenue, Millville, NJ 08332

${ }^{3}$ Department of Plant Biology, Rutgers University; and New Jersey Center for Wine Research and Education, Rutgers Agricultural Research and Extension Center, 121 Northville Road, Bridgeton, NJ 08302

${ }^{4}$ Department of Plant Biology, Rutgers University, Rutgers Agricultural Research and Extension Center, 121 Northville Road, Bridgeton, NJ 08302

${ }^{5}$ Extension Specialist in Vegetable Pathology

${ }^{6}$ Cumberland County Agricultural Agent

${ }^{7}$ Associate Extension Specialist in Pomology

${ }^{8}$ Director

${ }^{9}$ Former Field Researcher IV

${ }^{10}$ Corresponding author. E-mail: wyenandt@rutgers. edu.

doi: 10.21273/HORTTECH03144-16 the causal agent of phytophthora blight, causes serious economic losses to many Solanaceae and Cucurbitaceae crops in many vegetable production regions of the United States (Babadoost and Zitter, 2009; Barksdale et al., 1984; Hausbeck and Lamour, 2004). On many vegetable farms in southern New Jersey, $P$. capsici has become established in fields because of poor crop rotations. The overuse of the Fungicide Resistance Action Committee (FRAC) group 4 fungicide, mefenoxam, has led to the development of mefenoxam-insensitive P. capsici on some vegetable farms in New Jersey and in many other vegetable production regions of the United States (Café-Filho and Ristaino, 2008;
Hausbeck and Lamour, 2004; Keinath, 2007; Kline et al., 2011; Parra and Ristaino, 2001). Since P. capsici and mefenoxam insensitivity are both wide spread in the southern vegetable production region of the state, many bell pepper growers have adopted the use of phytophthora-resistant or -tolerant cultivars during the past 15 years. In New Jersey, the use of bell pepper cultivars such as Paladin or Aristotle, both with resistance to the crown rot phase of the pathogen, make up more than $50 \%$ of the total annual production acreage. The use of resistant cultivars has been estimated to save growers from $100 \%$ loss in some years (Rutgers University, 2005).

Recent research has suggested that $P$. capsici consists of 14 different races based on differential lines and virulence testing, and suggests that virulence differs in isolates from the same region (Foster and Hausbeck, 2010; Glosier et al., 2008; Sy et al., 2008). Since the early 1990s, researchers in New Jersey have cooperated with commercial seed companies to help determine if specific breeding lines or cultivars exhibit resistance or tolerance to local isolates of $P$. capsici. Observations made during these evaluations under New Jersey growing conditions have determined that certain cultivars and breeding lines with resistance or tolerance to the crown rot phase of $P$. capsici have exhibited what is now generically referred to as skin separation, or "silvering," of bell pepper fruit (Fig. 1). Skin separation reduces aesthetic fruit quality and its presence on fruit can be used to reduce quality grades. Currently, there is no evidence that skin separation reduces shelf life of fresh market fruit or the quality of fruit for processing. Although skin separation was noticed in cultivars and breeding lines during evaluations in the late-1990s and early-2000s, no research was done in New Jersey to determine the potential

\begin{tabular}{llll}
\hline $\begin{array}{l}\text { Units } \\
\text { To convert U.S. to SI, } \\
\text { multiply by }\end{array}$ & U.S. unit & SI unit & $\begin{array}{l}\text { To convert SI to U.S., } \\
\text { multiply by }\end{array}$ \\
\hline 0.4047 & $\mathrm{acre}(\mathrm{s})$ & $\mathrm{ha}$ & 2.4711 \\
29.5735 & $\mathrm{fl} \mathrm{oz}$ & $\mathrm{mL}$ & 0.0338 \\
0.0731 & $\mathrm{fl} \mathrm{oz} / \mathrm{acre}$ & $\mathrm{L} \cdot \mathrm{ha}^{-1}$ & 13.6840 \\
9.3540 & gal/acre & $\mathrm{L} \cdot \mathrm{ha}^{-1}$ & 0.1069 \\
2.54 & inch $(\mathrm{es})$ & $\mathrm{cm}$ & 0.3937 \\
0.4536 & $\mathrm{lb}$ & $\mathrm{kg}$ & 2.2046 \\
1.1209 & $\mathrm{lb} / \mathrm{acre}$ & $\mathrm{kg} \cdot \mathrm{ha}^{-1}$ & 0.8922
\end{tabular}




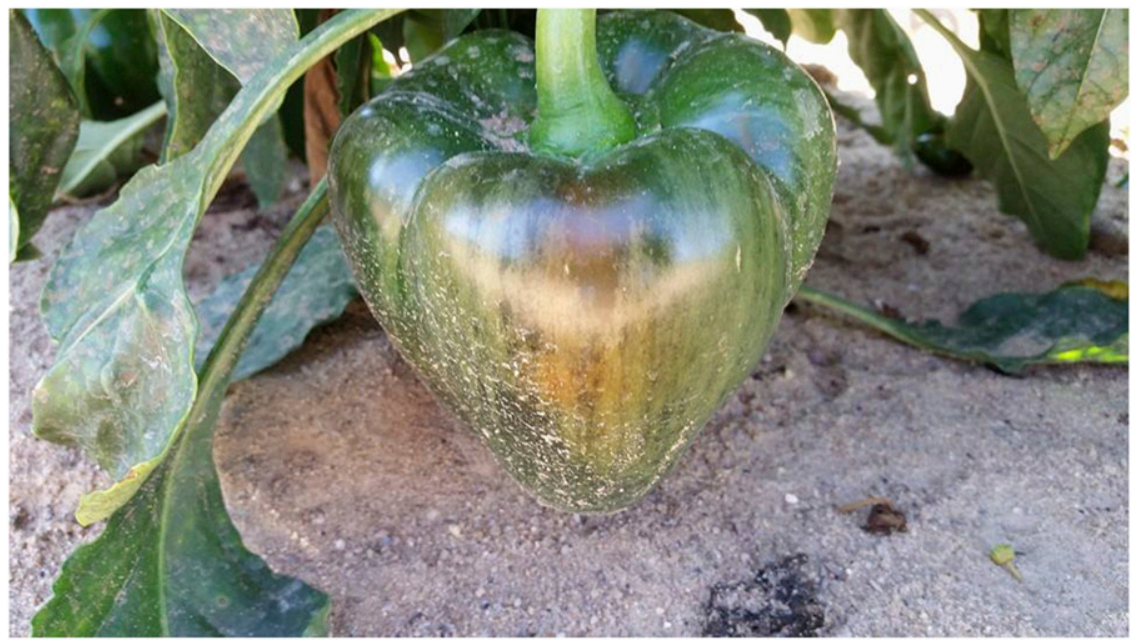

Fig. 1. Mature bell pepper fruit with "silvering."

cause. Only after bell pepper cultivars with tolerance to the crown rot phase of phytophthora blight were commercially released, and appreciable amounts of skin separation developed on bell pepper fruit, did the USDA set guidelines on its allowable limit. Current USDA guidelines label skin separation as a "silvery white discoloration" defect which appears as "diffused or solid silvery white areas" on fruit (USDA, 2016). Because phytophthora-tolerant and -resistant bell pepper cultivars make up more than $50 \%$ of the total bell pepper acreage in southern New Jersey, many growers are at risk for reduced quality and grade rejections due to skin separation. In New Jersey, skin separation has been reported to be as high as $66 \%$ in some phytophthora-tolerant cultivars at some harvests (Kline et al., 2011). Preliminary research on the possible relationship between the development of skin separation and phytophthora tolerance suggests that genotype may influence the amount of skin separation development in bell pepper fruit (Kline et al., 2011; Wyenandt and Kline, 2006; Wyenandt et al., 2007).

The objectives of this study were to determine the effects of four different production systems and five bell pepper cultivars considered susceptible, tolerant, or resistant to the crown rot phase of $P$. capsici on the development of skin separation in bell pepper fruit.

\section{Materials and methods}

From 2006 to 2008, four different production systems and five cultivars with varying levels of resistance to the crown rot phase of $P$. capsici were evaluated for their effects on the development of skin separation in bell pepper fruit at four vegetable farms in southern New Jersey (Table 1). The production system of each vegetable farm was also duplicated each year in a randomized complete block design with four replications at the Rutgers Agricultural Research and Extension Center (RAREC) in Bridgeton, NJ. The five bell peppers evaluated included phytophthora-susceptible 'Alliance' (Harris Moran Seed Co., Modesto, CA) and 'Camelot' (Stokes Seeds, Buffalo, NY); phytophthoratolerant 'Revolution' (Harris Moran Seed Co.); and phytophthora-resistant 'Aristotle' (Seminis, St. Louis, MO) and 'Paladin' (Syngenta Seeds, Wilmington, DE). The production systems used at each on-farm site represents one of four different types of bell or nonbell pepper production systems used by growers in southern New Jersey (Table 1). Each vegetable farm, referred to as on-farm site or by the farm name, differed based on the type of bed system, in-row plant spacing, irrigation method, and seasonlong fertility program (Table 1 ). Importantly, fields used in each year of the study at each on-farm location in or near Vineland, NJ, and at RAREC had a history of bell pepper production and losses due to P. capsici.

Planting Dates. In each year of the study, 8- to 10-week-old bell pepper transplants were obtained from a local supplier and set outdoors for 7 to $10 \mathrm{~d}$ before transplanting. Imidacloprid (Bayer CropScience, Research Triangle Park, NC) was applied as a drench at a rate of $0.25 \mathrm{fl} \mathrm{oz} /$ 10,000 plants to all transplants 1 $\mathrm{d}$ before transplanting. All five bell pepper cultivars were transplanted by hand on 1 June 2006, 17 May 2007, and 13 June 2008 at RAREC near Bridgeton, NJ; and on 18 May 2006, 17 May 2007, and 22 May 2008 at the Sheppard Farm in Cedarville, NJ; on 22 May 2006, 17 May 2007, and 3 June 2008 at the Laning Farm in Cedarville, NJ; on 19 May 2006, 17 May 2007, and 30 May 2008 at the Martino Farm in Vineland, NJ; and on 17 May 2007 and 30 May 2008 at the Flaim Farm in Vineland, NJ. Each onfarm site was planted in a commercial bell pepper field. Each transplant received $8.0 \mathrm{fl} \mathrm{oz} /$ acre of a $10 \mathrm{~N}-4.4 \mathrm{P}-$ $8.3 \mathrm{~K}$ starter fertilizer (J.R. Peters, Allentown, PA) at transplanting. During the production season at each on-farm site, season-long fertility, fungicide, and insect maintenance programs were done by the cooperator according to that operator's production methods. Fungicide and insect maintenance programs were also performed according to local commercial production practices at RAREC.

SEASON-LONG FERTILITY PROGRAMS FOR FOUR DIFFERENT BELL PEPPER PRODUCTION SYSTEMS IN SOUThern New Jersey. At RAREC in each year, $60 \mathrm{lb} /$ acre nitrogen $(\mathrm{N})$ in the form of calcium nitrate $(15.5 \mathrm{~N}-$ 0P-0K Tropicote; Yara North America, Tampa, FL) was incorporated before bed formation. The rates and timing of weekly fertility programs according to each on-farm cooperator's production system were duplicated at RAREC each year. The season-long fertility programs at the on-farm sites and RAREC were as follows.

At the Sheppard Farm, I gal/ acre 4N-0P-6.6K (Crop Production Services, Loveland, CO) plus 0.30 gal/acre 9N-0P-0K-11Ca (Viking Ship, Yara North America) plus boron (U.S. Borax, Valencia, CA) at $1 \mathrm{lb} /$ acre alternated weekly with $0.75 \mathrm{gal} /$ acre $9 \mathrm{~N}-0 \mathrm{P}-0 \mathrm{~K}+11 \mathrm{Ca}$ plus boron (U.S. Borax) at $1 \mathrm{lb} /$ acre for $\approx 14$ to 16 weeks in each year of the study. A total amount of $128 \mathrm{lb} /$ acre $\mathrm{N}$ was applied in each season.

At the Laning Farm, $15 \mathrm{gal} /$ acre $9 \mathrm{~N}-2.2 \mathrm{P}-7.5 \mathrm{~K}$ (Crop Production Services) was applied through drip application at transplanting plus $2.0 \mathrm{gal} /$ acre $4 \mathrm{~N}-0 \mathrm{P}-6.6 \mathrm{~K}$ via drip irrigation every $10 \mathrm{~d}$ for $\approx 11$ total applications 
Table 1. Production methods for the four types of cultural systems used in bell pepper research trials at four on-farm sites near Vineland, NJ, and the Rutgers Agricultural Research and Extension Center in Bridgeton, NJ, from 2006 to 2008.

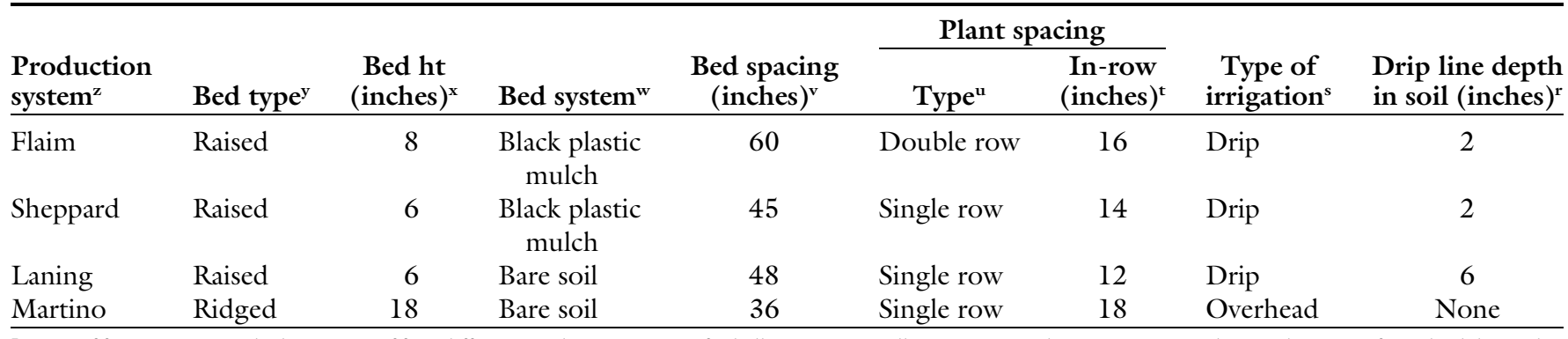

${ }^{\mathrm{z}}$ Name of farm operation which uses one of four different production systems for bell peppers typically grown in southern New Jersey. Flaim and Martino farms both located in

Vineland, NJ, and Sheppard and Laning farms were located near Cedarville, NJ.

yplanting beds made by a bedmaker which results in elevated (i.e., raised) bed or made by bedmaker which results in a ridged, or dome-shaped bed.

${ }^{\mathrm{x}}$ Maximum height of bed above cultivated soil line; $l$ inch $=2.54 \mathrm{~cm}$.

${ }^{\text {w}}$ Type of bed system using either black polyethylene plastic mulch or a bare soil (no mulch) production system.

"The distance between the centers of two beds in a given production system.

${ }^{u}$ Bell peppers were planted either in double (i.e., two rows per bed) or single (i.e., one row per bed).

${ }^{\mathrm{t}}$ The distance between two plants within a given row.

s Irrigation and/or fertility applied via drip tubing (i.e., drip tape) or overhead using a sprinkler system.

${ }^{\mathrm{r}}$ Depth of drip line below surface of the soil.

per season in each year of the study. A total of $249 \mathrm{lb} /$ acre $\mathrm{N}$ was applied each season.

At the Martino Farm, $40 \mathrm{lb} /$ acre $14 \mathrm{~N}-8.7 \mathrm{P}-11.6 \mathrm{~K}$ (Gromark FS, Milford, DE) plus $3.5 \mathrm{lb} /$ acre $0 \mathrm{~N}-0 \mathrm{P}-$ $49.8 \mathrm{~K}$ plus $2.4 \mathrm{lb} /$ acre $0 \mathrm{~N}-19.2 \mathrm{P}-$ $0 \mathrm{~K}$ was broadcast over the entire plot at transplanting and $\approx 10$ weeks later in each year of the study for a total of $140 \mathrm{lb} /$ acre $\mathrm{N}$ was applied in each season.

At the Flaim Farm in 2007 and $2008,4.0 \mathrm{lb} /$ acre $20 \mathrm{~N}-8.7 \mathrm{P}-16.6 \mathrm{~K}$ (Peters Professional 20-20-20; Scotts-Sierra Horticultural Products Co., Marysville, $\mathrm{OH}$ ) was applied weekly via drip application for 16 weeks in each year of the study for a total of $64 \mathrm{lb} /$ acre $\mathrm{N}$ was applied in each season.

Evaluations AND HARVEST DATES AT RAREC AND ON-FARM SITES. In each year of the study, all mature bell pepper fruit $(N=77,688)$ were harvested from each plot and visually evaluated for symptoms of skin separation or "silvering" (Fig. 1). All fruit were graded, counted, and weighed to determine the total number and weight (i.e., yield in number of 28-lb boxes per acre) of total marketable fruit, fruit with skin separation, and culled fruit (i.e., small or misshapen fruit). The percentage of total marketable fruit with visible symptoms of skin separation was also determined for each cultivar at each harvest.

At RAREC in 2006, all production systems were harvested on 2 and 15 Aug., 7 and 28 Sept., and 12 Oct.; in 2007, harvesting occurred on 25 July, 9 and 28 Aug., 12 and 25 Sept., and 19 Oct. (for Laning and Martino systems) and on 12 and 25 July, 9 and 28 Aug., 12 and 25 Sept., and 19 Oct. (for Flaim and Sheppard systems). In 2008, all four production systems were harvested on 11 and 25 Aug., 10 Sept., and 15 Oct. at RAREC.

At the Sheppard Farm in 2006, harvesting occurred on 24 July, 18 Aug., and 8 Sept.; in 2007, on 12 and 27 July, 8 and 24 Aug., 13 Sept., 1 and 24 Oct.; and in 2008, on 21 July, 12 and 28 Aug., 18 Sept., and 9 Oct. At the Laning Farm in 2006, harvesting occurred on 4 and 18 Aug., 8 and 29 Sept., and 11 Oct.; in 2007, on 12 and 24 July, 10 and 24 Aug., 13 Sept., 1 and 24 Oct.; and in 2008, on 24 July, 12 and 28 Aug., 18 Sept., and 9 Oct. At the Martino Farm in 2006 , harvesting occurred on 24 July, 11 Aug., 1 and 20 Sept., and 5 Oct.; in 2007, on 24 July, 10 and 24 Aug., 14 Sept., 4 and 25 Oct.; and in 2008, on 8 and 27 Aug., 23 Sept., and 10 Oct. At the Flaim Farm in 2007, harvesting occurred on 17 July, I and 15 Aug., 4 and 14 Sept., 4 and 24 Oct.; and in 2008, on 23 July, 7 and 27 Aug., 23 Sept., and 10 Oct.

Statistical analysis. The trial at RAREC and the on-farm trials were analyzed separately. For each response that was measured once per season (e.g., marketable yield), tests for main effects of year and cultivar as well as their interaction were performed using mixed effects analysis of variance (ANOVA). For responses measured at each harvest tests for main effects of year, production system, cultivar, and date of harvest, as well as their interactions were performed using a mixed effects repeated measures ANOVA. The MIXED procedure of SAS (version 9.13; SAS Institute, Cary, NC) was used for all statistical analyses. Block was included in the model as a random effect for analysis of the randomized complete block design. Model adequacy was evaluated graphically using plots of standardized residuals. Significant interactions were further investigated using Fisher's least significant difference for pairwise comparisons within each level of the interacting factor.

\section{RAREC results}

DEVELOPMENT OF SKIN SEPARATION AT RAREC FROM 2006 TO 2008. Cultivar, production system, and year each had a significant effect on the percentage of skin separation development in bell pepper fruit (Table $2)$. There was a significant three-way interaction between cultivar, production system, and year $(P<0.003)$. Therefore, mean separation for the total percentage of marketable fruit with skin separation across all harvest dates is presented separately by production system for each year (Table 2).

EFFECT OF CULTIVAR ON DEVELOPMENT OF SKIN SEPARATION IN BELL PEPPER FRUIT AT RAREC. Cultivar had a significant effect on the development of skin separation in bell pepper fruit (Table 2). In each year of the study at RAREC, the percentage of bell pepper fruit with 
skin separation was higher in phytophthora-resistant 'Aristotle' and 'Paladin' compared with phytophthora-tolerant 'Revolution' and phytophthorasusceptible 'Alliance' and 'Camelot' (Table 2).

TYPE OF PRODUCTION SYSTEM EFFECTS ON THE DEVELOPMENT OF SKIN SEPARATION IN BELL PEPPER FRUIT AT RAREC. There was a significant interaction between cultivar and production system $(P<0.0001$, Table 2). Overall, total silvering across all cultivars was $14 \%$ for bell peppers when grown in double rows on black plastic mulch with drip irrigation (Flaim system), 13\% when grown in a single row on black plastic mulch with drip irrigation (Sheppard system), 11\% when grown in single rows on raised, bare ground beds with buried drip irrigation (Laning system), and $8 \%$ when grown in single rows on high, ridged beds with overhead irrigation (Martino system) (data not shown).

In each year of the study where bell peppers were grown in single rows on high, ridged beds with overhead irrigation (Martino system) at RAREC, the percentage of fruit with skin separation was higher in both phytophthora-resistant cultivars compared with the phytophthorasusceptible cultivars (Table 2). In all 3 years, the incidence of skin separation was higher in phytophthora-resistant 'Paladin' compared with phytophthoraresistant 'Aristotle' (Table 2). Additionally, there were no significant differences between both phytophthora-susceptible cultivars, or between both susceptible cultivars and phytophthora-tolerant Revolution (Table 2).

When bell peppers were grown in single rows on raised, bare ground beds with buried drip irrigation (Laning system) at RAREC, the percentage of fruit with skin separation was significantly higher in the phytophthoraresistant cultivars compared with phytophthora-susceptible cultivars and phytophthora-tolerant Revolution (Table 2). The occurrence of skin separation was significantly higher in phytophthora-resistant 'Aristotle' compared with 'Paladin' in 1 of 3 years (Table 2). No significant differences were noted between both susceptible cultivars, or between both susceptible cultivars and phytophthora-tolerant Revolution in 2006 and 2008; however, in 2007, skin separation was

Table 2. Percentage of "silvering" or skin separation in total harvested fruit of five bell pepper cultivars with either Phytophthora capsici resistance, tolerance, or susceptibility grown in four different production systems from 2006 to 2008 at the Rutgers Agricultural Research and Extension Center in Bridgeton, NJ.

\begin{tabular}{|c|c|c|c|}
\hline \multirow[b]{2}{*}{ Cultivar $^{\mathrm{z}}$} & \multicolumn{3}{|c|}{ Total skin separation (\%) } \\
\hline & 2006 & 2007 & 2008 \\
\hline & \multicolumn{3}{|c|}{ Martino system ${ }^{\mathrm{y}}$} \\
\hline Camelot & $1 c^{x}$ & $8 \mathrm{c}$ & $1 \mathrm{bc}$ \\
\hline Alliance & $1 \mathrm{c}$ & $10 \mathrm{c}$ & $1 \mathrm{c}$ \\
\hline Revolution & $3 \mathrm{bc}$ & $5 \mathrm{c}$ & $1 \mathrm{c}$ \\
\hline Aristotle & $7 \mathrm{~b}$ & $20 \mathrm{~b}$ & $7 \mathrm{~b}$ \\
\hline \multirow[t]{2}{*}{ Paladin } & $15 \mathrm{a}$ & $33 \mathrm{a}$ & $16 \mathrm{a}$ \\
\hline & \multicolumn{3}{|c|}{ Laning system } \\
\hline Camelot & $\mathrm{lb}$ & $2 \mathrm{c}$ & $3 c$ \\
\hline Alliance & $3 \mathrm{~b}$ & $2 \mathrm{c}$ & $1 \mathrm{c}$ \\
\hline Revolution & $4 \mathrm{~b}$ & $9 \mathrm{~b}$ & $1 \mathrm{c}$ \\
\hline Aristotle & $19 \mathrm{a}$ & $24 \mathrm{a}$ & $33 \mathrm{a}$ \\
\hline \multirow[t]{2}{*}{ Paladin } & $16 \mathrm{a}$ & $24 \mathrm{a}$ & $27 \mathrm{~b}$ \\
\hline & \multicolumn{3}{|c|}{ Sheppard system } \\
\hline Camelot & $4 \mathrm{~b}$ & $8 \mathrm{bc}$ & $2 \mathrm{~b}$ \\
\hline Alliance & $8 \mathrm{~b}$ & $6 \mathrm{c}$ & $1 \mathrm{~b}$ \\
\hline Revolution & $4 \mathrm{~b}$ & $13 \mathrm{~b}$ & $5 \mathrm{~b}$ \\
\hline Aristotle & $18 \mathrm{a}$ & $24 \mathrm{a}$ & $29 \mathrm{a}$ \\
\hline \multirow[t]{2}{*}{ Paladin } & $22 \mathrm{a}$ & $27 \mathrm{a}$ & $23 \mathrm{a}$ \\
\hline & \multicolumn{3}{|c|}{ Flaim system } \\
\hline Camelot & $12 \mathrm{c}$ & $5 \mathrm{~b}$ & $5 \mathrm{~b}$ \\
\hline Alliance & $7 \mathrm{c}$ & $4 \mathrm{~b}$ & $4 \mathrm{~b}$ \\
\hline Revolution & $9 \mathrm{c}$ & $4 \mathrm{~b}$ & $6 \mathrm{~b}$ \\
\hline Aristotle & $32 \mathrm{a}$ & $16 \mathrm{a}$ & $32 \mathrm{a}$ \\
\hline \multirow[t]{2}{*}{ Paladin } & $26 \mathrm{~b}$ & $20 \mathrm{a}$ & $31 \mathrm{a}$ \\
\hline & \multicolumn{3}{|c|}{ ANOVA } \\
\hline Cultivar (CV) & \multicolumn{3}{|c|}{$<0.0001$} \\
\hline Production system (PS) & \multicolumn{3}{|c|}{$<0.0001$} \\
\hline Year (YR) & \multicolumn{3}{|c|}{0.0087} \\
\hline $\mathrm{CV} \times \mathrm{PS}$ & \multicolumn{3}{|c|}{$<0.0001$} \\
\hline $\mathrm{CV} \times \mathrm{YR}$ & \multicolumn{3}{|c|}{$<0.0001$} \\
\hline $\mathrm{PS} \times \mathrm{YR}$ & \multicolumn{3}{|c|}{$<0.0001$} \\
\hline $\mathrm{CV} \times \mathrm{PS} \times \mathrm{YR}$ & \multicolumn{3}{|c|}{0.0003} \\
\hline
\end{tabular}

ANOVA = analysis of variance.

${ }^{\mathrm{z} B e l l}$ pepper cultivars with no resistance (Alliance or Camelot), tolerance (Revolution), or resistance (Aristotle or Paladin) to the crown rot phase of $P$. capsici.

${ }^{y}$ Farm name (see Table 1 for details on type of production system).

${ }^{\mathrm{x}}$ Means within a year (column) and production system followed by the same letter are not significantly different according to Fisher's protected least significant difference test at $\alpha=0.05$

significantly higher in Revolution compared with both susceptible cultivars (Table 2).

For bell peppers grown in single rows on raised beds with black plastic mulch with drip irrigation (Sheppard system) at RAREC, the percentage of fruit with skin separation was significantly higher in the phytophthoraresistant cultivars compared with the phytophthora-tolerant Revolution and the phytophthora-susceptible cultivars (Table 2). There were no significant differences in percent skin separation between the resistant cultivars in each year (Table 2). In each year, there were no significant differences between the two susceptible cultivars (Table 2 ). In 1 of 3 years, the percentage of fruit with skin separation was significantly higher in ' $\mathrm{Rev}$ olution' compared with 'Alliance' (Table 2).

In each year of the study, when bell peppers were grown in double rows on raised beds with black plastic mulch with drip irrigation (Flaim system) at RAREC, the percentage of fruit with skin separation was significantly higher in the phytophthoraresistant cultivars Aristotle and Paladin compared with the phytophthoratolerant cultivar Revolution and both phytophthora-susceptible cultivars (Table 2 ). There was a significant difference in skin separation between resistant 
cultivars Aristotle and Paladin in 2006 but not in other years (Table 2). Additionally, there were no significant difference between both phytophthorasusceptible cultivars and 'Revolution' in each year of the study (Table 2).

PRODUCTION SYSTEM AND CULTIVAR EFFECT ON MARKETABLE YIELD AT RAREC. Cultivar, production system, and year each had a significant effect on the marketable yield, and there was a significant three-way interaction between cultivar, production system, and year $(P<$ $0.001)$. Therefore, mean separation for marketable yield of the five cultivars of bell pepper is presented separately by production system for each year (Table 3). In general at RAREC, marketable yield was highest among cultivars when bell peppers were grown in double rows on raised beds with black plastic mulch with drip irrigation (Flaim system) followed by bell peppers on single rows on raised beds with black plastic mulch and drip irrigation (Sheppard system) then bell peppers grown on single rows on raised, bare ground beds with buried drip irrigation (Laning system) (Table 3). Marketable yields were lowest when bell peppers were grown in single rows on high, ridged beds with overhead irrigation (Martino system). Year had no significant effect on marketable yield $(P=0.15$, Table 3 ).

In 2006 and 2007, where bell peppers were grown in single rows on high, ridged beds with overhead irrigation (Martino system), there were no significant differences in marketable yield among cultivars (Table 3 ). However, in 2008, marketable yield was significantly lower in phytophthora-resistant 'Paladin' compared with both phytophthora-susceptible cultivars (Table 3 ).

When bell peppers were grown in single rows on raised, bare soil beds with buried drip irrigation (Laning system) in 2006, marketable yield was significantly lower in phytophthora-resistant 'Aristotle' compared with phytophthorasusceptible 'Alliance' and phytophthoratolerant 'Revolution'. In 2007, yields were lower in both resistant cultivars compared with phytophthora-susceptible Alliance and phytophthora-tolerant Revolution. In 2008, yield was significantly higher in phytophthorasusceptible 'Alliance' and phytophthoratolerant 'Revolution' compared with the three other cultivars (Table 3).

Table 3. Marketable bell pepper yield in total number of $28-1 \mathrm{~b}(12.7 \mathrm{~kg})$ boxes per acre at the Rutgers Agricultural Research and Extension Center in Bridgeton, NJ, from 2006 to 2008.

\begin{tabular}{|c|c|c|c|}
\hline \multirow[b]{2}{*}{ Cultivar $^{\mathrm{z}}$} & \multicolumn{3}{|c|}{ Marketable yield (boxes/acre) ${ }^{y}$} \\
\hline & 2006 & 2007 & 2008 \\
\hline & \multicolumn{3}{|c|}{ Martino system $^{\mathrm{x}}$} \\
\hline Camelot & $321 a^{w}$ & 366 a & $423 \mathrm{a}$ \\
\hline Alliance & 377 a & $339 a$ & $436 \mathrm{a}$ \\
\hline Revolution & $322 \mathrm{a}$ & $302 \mathrm{a}$ & $329 a b$ \\
\hline Aristotle & $242 \mathrm{a}$ & $376 a$ & $302 \mathrm{ab}$ \\
\hline \multirow[t]{2}{*}{ Paladin } & $210 \mathrm{a}$ & 293 a & $238 \mathrm{~b}$ \\
\hline & \multicolumn{3}{|c|}{ Laning system } \\
\hline Camelot & $538 \mathrm{bc}$ & $603 \mathrm{bc}$ & $682 \mathrm{~b}$ \\
\hline Alliance & $721 \mathrm{a}$ & 798 a & $901 \mathrm{a}$ \\
\hline Revolution & $713 \mathrm{ab}$ & $743 \mathrm{ab}$ & 879 a \\
\hline Aristotle & $500 \mathrm{c}$ & $543 c$ & $613 b$ \\
\hline \multirow[t]{2}{*}{ Paladin } & $559 \mathrm{abc}$ & $544 \mathrm{c}$ & $611 b$ \\
\hline & \multicolumn{3}{|c|}{ Sheppard system } \\
\hline Camelot & $618 \mathrm{~b}$ & $1,202 \mathrm{a}$ & $655 \mathrm{~b}$ \\
\hline Alliance & 808 a & $1,175 \mathrm{a}$ & 936 a \\
\hline Revolution & $690 \mathrm{ab}$ & $1,097 \mathrm{ab}$ & 890 a \\
\hline Aristotle & $562 \mathrm{~b}$ & $980 \mathrm{~b}$ & $617 b$ \\
\hline \multirow[t]{2}{*}{ Paladin } & $610 \mathrm{~b}$ & $950 \mathrm{~b}$ & $654 \mathrm{~b}$ \\
\hline & \multicolumn{3}{|c|}{ Flaim system } \\
\hline Camelot & $1,200 \mathrm{bc}$ & $1,544 \mathrm{a}$ & $1,090 \mathrm{c}$ \\
\hline Alliance & $1,832 \mathrm{a}$ & $1,480 \mathrm{a}$ & 1,788 a \\
\hline Revolution & 2,005 a & $1,268 \mathrm{~b}$ & $1,836 \mathrm{a}$ \\
\hline Aristotle & $1,162 \mathrm{c}$ & $1,236 \mathrm{~b}$ & $1,309 \mathrm{~b}$ \\
\hline \multirow[t]{2}{*}{ Paladin } & $1,351 \mathrm{~b}$ & $1,044 \mathrm{c}$ & $1,186 \mathrm{bc}$ \\
\hline & & ANOVA & \\
\hline Cultivar (CV) & & $<0.0001$ & \\
\hline Production system (PS) & & $<0.0001$ & \\
\hline Year (YR) & & 0.15 & \\
\hline $\mathrm{CV} \times \mathrm{PS}$ & & $<0.0001$ & \\
\hline $\mathrm{CV} \times \mathrm{YR}$ & & $<0.0001$ & \\
\hline $\mathrm{PS} \times \mathrm{YR}$ & & $<0.0001$ & \\
\hline $\mathrm{CV} \times \mathrm{PS} \times \mathrm{YR}$ & & $<0.0001$ & \\
\hline
\end{tabular}

ANOVA $=$ analysis of variance.

${ }^{\mathrm{z}}$ Bell pepper cultivars with no resistance (Alliance or Camelot), tolerance (Revolution), or resistance (Aristotle or Paladin) to the crown rot phase of Phytophthora capsici.

${ }^{\mathrm{y}}$ Marketable yield consists of all peppers harvested of medium $(0.25-0.32 \mathrm{lb})$, large $(0.33-0.49 \mathrm{lb})$ and extralarge $(\geq 0.50 \mathrm{lb})$ sized fruit with and without "silvering"; $1 \mathrm{lb}=0.4536 \mathrm{~kg}, 128-\mathrm{lb}$ box $/$ acre $=31.3838 \mathrm{~kg} \cdot \mathrm{ha}^{-1}$. ${ }^{\mathrm{x}}$ Farm name (see Table 1 for details on type of production system).

${ }^{w}$ Means within a column (year) and production system followed by the same letter are not significantly different according to Fisher's protected least significant difference test at $\alpha=0.05$.

For bell peppers grown in single rows on raised beds with black plastic mulch and drip irrigation (Sheppard system), marketable yield was significantly higher in phytophthorasusceptible 'Alliance' compared with phytophthora-susceptible 'Camelot' and both phytophthora-resistant cultivars in 2006 (Table 3 ). In 2007, yields were higher in both phytophthora-susceptible cultivars compared with both resistant cultivars. Marketable yields were similar between both phytophthora-susceptible cultivars and phytophthora-tolerant Revolution in 2007 (Table 3). In 2008, yields were significantly higher in the phytophthora-susceptible 'Alliance' and phytophthora-tolerant 'Revolution' compared with the three other cultivars (Table 3 ).

In bell peppers grown in double rows on raised beds with black plastic mulch with drip irrigation (Flaim system) in 2006, marketable yields were significantly higher in phytophthorasusceptible cultivar Alliance and phytophthora-tolerant Revolution compared with the three other cultivars and lowest in phytophthoraresistant Aristotle (Table 3). In 2007, marketable yield was significantly lower in phytophthora-resistant cultivar Paladin compared with the other four cultivars, and higher in both phytophthora-susceptible cultivars 
compared with phytophthora-tolerant Revolution and phytophthora-resistant Aristotle (Table 3). In 2008, marketable yields were significantly higher in phytophthora-susceptible cultivar Alliance and phytophthora-tolerant Revolution compared with the other three cultivars and lowest in phytophthorasusceptible Camelot (Table 3).

\section{On-farm results}

DEVELOPMENT OF SKIN SEPARATION AND MARKETABLE YIELD AT FOUR ON-FARM SITES IN SOUTHERN NeW Jersey From 2006 to 2008. Because each on-farm site had a different production system (i.e., type of bed system, fertility program, different harvest dates), direct comparisons could not be made on a yearly basis. Therefore, the development of skin separation and differences in marketable yield in cultivars at each location were examined separately each year (Tables 4 and 5). Cultivar had a significant effect on the amount of skin separation development within each production system at each on-farm site during the 3 years of this study (Table 4). Year also had a significant effect on the percentage of skin separation in two (i.e., Martino and Laning systems) of the four production systems (Table 5). There was a significant interaction between cultivar and year for the development of skin separation in the Martino and Laning systems (e.g., both bare soil production systems), but no cultivar by year interaction for the Sheppard or Flaim systems (e.g., both production systems using black plastic mulch) (Table 4). In each year across all production systems, more skin separation was present in phytophthoraresistant 'Paladin' and 'Aristotle' compared with the phytophthora-tolerant 'Revolution' or phytophthora-susceptible 'Alliance' and 'Camelot' (Table 5).

Production SYSTEM AND CULTIVAR EFFECT ON MARKETABLE PEPPER YIELD AT FOUR ON-FARM SITES IN SOUTHERN NEW JERSEY FROM 2006 To 2008. With the exception of the Martino system, cultivar had a significant effect on marketable yield

Table 4. Total percentage of skin separation or "silvering" in total harvested fruit of five bell pepper cultivars with either Phytophthora capsici resistance, tolerance, or susceptibility grown in four different production systems at four on-farm sites near Vineland, NJ, from 2006 to 2008.

\begin{tabular}{|c|c|c|c|c|c|c|c|c|c|c|c|c|}
\hline \multirow[b]{3}{*}{ Cultivar $^{\mathrm{z}}$} & \multicolumn{12}{|c|}{ Total skin separation (\%) } \\
\hline & \multicolumn{3}{|c|}{ Martino system ${ }^{\mathrm{y}}$} & \multicolumn{3}{|c|}{ Laning system } & \multicolumn{3}{|c|}{ Sheppard system } & \multicolumn{3}{|c|}{ Flaim system } \\
\hline & 2006 & 2007 & 2008 & 2006 & 2007 & 2008 & 2006 & 2007 & 2008 & 2006 & 2007 & 2008 \\
\hline Alliance & $2 \mathrm{c}$ & $2 c$ & $0.3 \mathrm{~b}$ & $2 c$ & $3 \mathrm{~b}$ & $3 c$ & $3 \mathrm{~b}$ & $6 \mathrm{~b}$ & $7 \mathrm{~b}$ & NA & $7 \mathrm{~b}$ & $7 \mathrm{c}$ \\
\hline Revolution & $2 c$ & $10 \mathrm{~b}$ & $1 \mathrm{~b}$ & $1 \mathrm{c}$ & $7 \mathrm{~b}$ & $7 \mathrm{c}$ & $6 \mathrm{~b}$ & $10 \mathrm{~b}$ & $8 \mathrm{~b}$ & NA & $8 \mathrm{~b}$ & $12 \mathrm{~b}$ \\
\hline Aristotle & $11 \mathrm{~b}$ & $26 \mathrm{a}$ & $4 \mathrm{ab}$ & $18 \mathrm{~b}$ & $21 \mathrm{a}$ & $26 \mathrm{~b}$ & $27 \mathrm{a}$ & $30 \mathrm{a}$ & $25 \mathrm{a}$ & NA & $38 \mathrm{a}$ & $37 \mathrm{a}$ \\
\hline Cultivar (CV) & \multicolumn{3}{|c|}{$<0.0001$} & \multicolumn{3}{|c|}{$<0.0001$} & \multicolumn{3}{|c|}{$<0.0001$} & \multicolumn{3}{|c|}{$<0.0001$} \\
\hline Year (YR) & \multicolumn{3}{|c|}{$<0.0001$} & \multirow{2}{*}{\multicolumn{3}{|c|}{0.0141}} & \multirow{2}{*}{\multicolumn{3}{|c|}{0.1327}} & \multicolumn{3}{|c|}{0.1327} \\
\hline $\mathrm{CV} \times \mathrm{YR}$ & \multicolumn{3}{|c|}{0.0002} & & & & 0.5989 & & & \multicolumn{3}{|c|}{0.5432} \\
\hline
\end{tabular}

ANOVA = analysis of variance.

${ }^{z}$ Bell pepper cultivars with no resistance (Alliance or Camelot), tolerance (Revolution), or resistance (Aristotle or Paladin) to the crown rot phase of $P$. capsici.

${ }^{y}$ Farm name (see Table 1 for details on type of production system).

${ }^{x}$ Means within a column and production system followed by the same letter are not significantly different according to Fisher's protected least significant difference test at $\alpha=0.05$.

${ }^{\mathrm{w}} \mathrm{NA}=$ trial was not done at Flaim Farm in 2006

Table 5. Marketable yield in total number of $28-1 \mathrm{~b}(12.7 \mathrm{~kg})$ boxes per acre of five bell pepper cultivars grown in four different production systems at four on-farm sites near Vineland, NJ, from 2006 to 2008.

\begin{tabular}{|c|c|c|c|c|c|c|c|c|c|c|c|c|}
\hline \multirow[b]{3}{*}{ Cultivar $^{\mathrm{z}}$} & \multirow{2}{*}{\multicolumn{3}{|c|}{ Martino system $^{\mathrm{x}}$}} & \multicolumn{6}{|c|}{ Total marketable yield (boxes/acre) ${ }^{y}$} & & & \\
\hline & & & & \multicolumn{3}{|c|}{ Laning system } & \multicolumn{3}{|c|}{ Sheppard system } & \multicolumn{3}{|c|}{ Flaim system } \\
\hline & 2006 & 2007 & 2008 & 2006 & 2007 & 2008 & 2006 & 2007 & 2008 & 2006 & 2007 & 2008 \\
\hline Alliance & $209 \mathrm{a}$ & $493 \mathrm{~b}$ & $319 \mathrm{a}$ & $768 \mathrm{a}$ & $1,606 \mathrm{bc}$ & $1,242 \mathrm{a}$ & $92 \mathrm{a}$ & $1,612 b$ & 1,592 a & NA & $2,368 \mathrm{~b}$ & $1,895 \mathrm{~b}$ \\
\hline Revolution & $210 a$ & $660 a$ & $318 \mathrm{a}$ & $337 c$ & $1,866 \mathrm{a}$ & $1,265 \mathrm{a}$ & $272 \mathrm{a}$ & $2,057 \mathrm{a}$ & $1,489 \mathrm{a}$ & NA & $3,134 \mathrm{a}$ & $2,742 \mathrm{a}$ \\
\hline Aristotle & $322 \mathrm{a}$ & $634 \mathrm{ab}$ & $290 \mathrm{a}$ & $674 \mathrm{ab}$ & $1,266 \mathrm{~d}$ & $950 \mathrm{~b}$ & $219 a$ & $1,242 \mathrm{c}$ & $1,241 \mathrm{~b}$ & NA & $1,841 \mathrm{c}$ & $1,685 \mathrm{~b}$ \\
\hline Cultivar $(\mathrm{CV})$ & & 0.1132 & & & $<0.001$ & & & $<0.001$ & & & $<0.001$ & \\
\hline Year (YR) & & 0.0006 & & & $<0.001$ & & & $<0.001$ & & & 0.0614 & \\
\hline $\mathrm{CV} \times \mathrm{YR}$ & & 0.4798 & & & $<0.001$ & & & $<0.001$ & & & 0.7307 & \\
\hline
\end{tabular}

ANOVA = analysis of variance.

${ }^{z}$ Bell pepper cultivars with no resistance (Alliance or Camelot), tolerance (Revolution), or resistance (Aristotle or Paladin) to the crown rot phase of Phytophthora capsici.

${ }^{\mathrm{y}}$ Marketable yield consists of all peppers harvested of medium $(0.25-0.32 \mathrm{lb})$, large $(0.33-0.49 \mathrm{lb})$ and extralarge $(\geq 0.50 \mathrm{lb})$ sized fruit with and without "silvering"; $1 \mathrm{lb}=$ $0.4536 \mathrm{~kg}, \mathrm{l} 28-\mathrm{lb}$ box $/$ acre $=31.3838 \mathrm{~kg} \cdot \mathrm{ha}^{-1}$.

${ }^{\mathrm{x}}$ Farm name (see Table 1 for details on type of production system).

${ }^{w}$ Means within a column and production system followed by the same letter are not significantly different according to Fisher's protected least significant difference test at $\alpha=0.05$.

${ }^{\mathrm{v}} \mathrm{NA}=$ Trial was not done at Flaim Farm in 2006 
(Table 5). With the exception of the Martino and Sheppard systems in 2006 and Martino production system in 2008, year had a significant effect on marketable yield among cultivars (Table 5 ). There was a cultivar by year interaction for the Laning and Sheppard systems, but not the Martino or Flaim systems (Table 5). Although no formal comparisons were done between the on-farm sites, in general, overall marketable yields were higher in the two production systems where peppers were grown in single (Sheppard system) or double rows (Flaim system) on black plastic mulch with black plastic mulch and drip irrigation compared with peppers grown in single rows in the bare soil production systems with overhead irrigation (Martino system) or buried drip irrigation (Laning system) during this study (Table 5).

\section{Discussion}

In each year of this study at RAREC, skin separation, or "silvering," was higher in the phytophthoraresistant 'Paladin' and 'Aristotle' compared with the phytophthoratolerant 'Revolution' or phytophthorasusceptible 'Camelot' and 'Alliance' regardless of the type of production system. This relationship between amount of skin separation development on fruit and phytophthora resistance was consistently present in the same cultivars across the different bell pepper production systems at four on-farm locations during the 3 years of this study. Kline et al. (2011) also showed that $\mathrm{N}$ fertility had no effect on the development of skin separation in bell pepper fruit in an evaluation of six different $\mathrm{N}$ fertility programs. In the same study, more skin separation developed in the phytophthora-resistant cultivar Aristotle than in phytophthora-susceptible Camelot regardless of $\mathrm{N}$ fertility regimen (Kline et al., 2011). These findings, and the results of this study, suggest that the development of skin separation in bell pepper fruit may be more closely associated with genotype (i.e., phytophthora resistance or susceptibility) than type of production system. Current research suggests there are at least 14 physiological races of $P$. capsici and that their virulence and distribution among pepper production regions of the United States may differ dramatically (Glosier et al., 2008; Hausbeck and Lamour, 2004). Thus, if bell pepper cultivars, germplasm, and breeding lines, which are more prone to skin separation are used to hybridize new cultivars for race-specific $P$. capsici resistance in different production regions, the likelihood for more skin separation-related issues in bell pepper production increases. More coordinated research on the genetic factors which lead to the development of skin separation in phytophthora-resistant bell peppers needs to be done by universities and seed companies to develop bell pepper cultivars with resistance to local races of $P$. capsici and which are less prone to the development of skin separation. Unless more is done from a breeding standpoint, skin separation will remain a significant problem for growers in the state. For example, in southern New Jersey, greater than $50 \%$ of the bell pepper acreage is currently planted in $P$. capsici-resistant cultivars annually. Issues related to skin separation will become increasingly important as P. capsici becomes more established in New Jersey and other bell pepper production areas of the United States and world, and as more acreage of phytophthora-resistant bell peppers are grown to prevent losses due to the crown rot phase of phytophthora blight.

Each bell pepper cultivar used in this study has been commonly grown in southern New Jersey in recent years. In this study, marketable bell pepper yields were highest when grown in staggered, double rows on raised beds with black plastic mulch and drip irrigation. Currently, over $90 \%$ of all bell and nonbell peppers in southern New Jersey are grown using this system. In this study and in general, marketable yields were highest in phytophthora-susceptible 'Alliance' and phytophthora-resistant 'Revolution'. Importantly, phytophthorasusceptible bell peppers cultivars are still recommended and can be grown successfully in southern New Jersey as long as fields are not heavily infested with $P$. capsici. In fields with a history of $P$. capsici, only phytophthoratolerant or -resistant cultivars should be grown. Regardless of cultivar, the use of fungicides such as mefenoxam, if insensitivity is not present, as well as the use and rotation of fungicides with different modes of action such as fluopicolide (FRAC group 43), mandipropamid (FRAC group 40), cyazofamid (FRAC group 21), and the phosphite fungicides (FRAC group 33) are recommended to help prevent $P$. capsici infection and reduce fungicide resistance development.

\section{Literature cited}

Babadoost, M. and T.A. Zitter. 2009. Fruit rots of pumpkin: A serious threat to the pumpkin industry. Plant Dis. 93:772782 .

Barksdale, T.H., G.C. Papvizas, and S.A. Johnston. 1984. Resistance to foliar blight and crown rot of pepper caused by Phytophthora capsici. Plant Dis. 68:506-509.

Café-Filho, A.C. and J.B. Ristaino. 2008. Fitness of isolates of Phytophthora capsici resistant to mefenoxam from squash and pepper fields in North Carolina. Plant Dis. 92:1439-1443.

Foster, J.M. and M.K. Hausbeck. 2010. Resistance of pepper to Phytophthora crown, root, and fruit rot is affected by isolate virulence. Plant Dis. 94:24-30.

Glosier, B.R, E.A. Ogundiwin, G.S. Sidhu, D.R. Sischo, and J.P. Prince. 2008. A differential series of pepper (Capsicum annumm) lines delineates fourteen physiological races of Phytophthora capsici. Euphytica 162:23-30.

Hausbeck, M.K. and K.H. Lamour. 2004. Phytophthora capsici on vegetable crops: Research progress and management challenges. Plant Dis. 88:1292-1303.

Kline, W.L., C.A. Wyenandt, D.L. Ward, J.F. Sudal, and N.L. Maxell. 2011. Evaluation of six nitrogen fertility programs on marketable yield and development of skin separation in bell pepper fruit. HortTechnology 21:323-328.

Keinath, A.P. 2007. Sensitivity of populations of Phytophthora capsici from South Carolina to mefenoxam, dimethomorph, zoxamide, and cymoxanil. Plant Dis. 91:743-748.

Parra, G. and J.B. Ristaino. 2001. Resistance to mefenoxam and metalaxyl among field isolates of Phytophthora capsici causing phytophthora blight of bell pepper. Plant Dis. 85:1069-1075.

Rutgers University. 2005. Crop profile for peppers (bell) in New Jersey. 20 Apr. 2016. <http://www.pestmanagement. rutgers.edu/NJinPAS/CropProfiles / NJPpeppercp05.pdf $>$.

Sy, O., R. Steiner, and P.W. Bosland. 2008. Recombinant inbred line differential identifies race-specific resistance to phytophthora root rot in Capsicum annumm. Phytopathology 98:867-870. 


\section{Research Reports}

U.S. Department of Agriculture. 2012. Census of agriculture. 27 Oct. 2016. <https://www.agcensus.usda.gov/ Publications/2012/\#full_report>.

U.S. Department of Agriculture. 2016. Peppers: Shipping point and market inspection instructions. 27 Oct. 2016. <https://www.ams.usda.gov/sites/
default/files/media/Pepper_including Sweet_and_Other_than_Sweet_types_ Inspection_Instructions.pdf $>$.

Wyenandt, C.A. and W.L. Kline. 2006. Evaluation of skin separation (silvering) in fruit of bell pepper cultivars. HortScience 41:494 (abstr.).
Wyenandt, C.A., W.L. Kline, D.L. Ward, J.F. Sudal, and N.L. Maxwell. 2007. Relationship between skin separation and phytophthora-resistance in bell pepper cultivars and breeding lines. Phytopathology 97:S125 (abstr.). 